\title{
Despite Some Success Stories, Policy Measures Lag Behind
}

\subsection{Introduction: some policy success stories exist, but they are not enough}

Examples of effective environmental policies and improvements exist, from the global to local levels especially where problems have been well identified and are manageable, and where regulatory and technological solutions are readily available (well established, but incomplete). All stakeholders (global institutions, local and national governments, businesses, communities and individuals) have roles to play in addressing environmental challenges. This section concentrates on responses at the international level and by national governments, but also acknowledges the important role of the private sector and local initiatives. New policies will be required if challenges are to be met effectively. However, much can also be achieved through more effective implementation and enforcement of existing policies and standards. \{Chapters 12 to 17 ; SPM Section 2\}

A growing framework of international agreements and initiatives covers various aspects of issues related to air, freshwater, land and soil, oceans and coasts, and biodiversity which are linked in an integrated manner through the SDGs. However, while individual agreements can address relatively simple issues, more societally and ecologically complex problems face major political opposition, resulting in reduced clarity regarding goals, targets, indicators, instruments, concomitant funding, monitoring and enforcement measures. Furthermore, these instruments are mostly reactive and have not yet targeted emerging issues such as sand mining, plastic in the oceans, antibiotic resistance, international land grabbing and many others. $\{18.1\}$

Among the examples of effective policies is the Montreal Protocol, which led to the decrease of emissions of ozone-depleting substances (well established). The ozone hole over Antarctica in September and October 2019 was the smallest observed at any time since 1982.

Many regulatory measures, including local and global environmental treaties and laws, have been qualified successes (established but incomplete). Many countries are using local or national regulatory measures to begin to reduce (if not yet control) plastic pollution. In many countries the coverage of terrestrial and marine protected areas has increased (Figure 4.1).

\section{Figure 4.1: Protected Areas of the World}

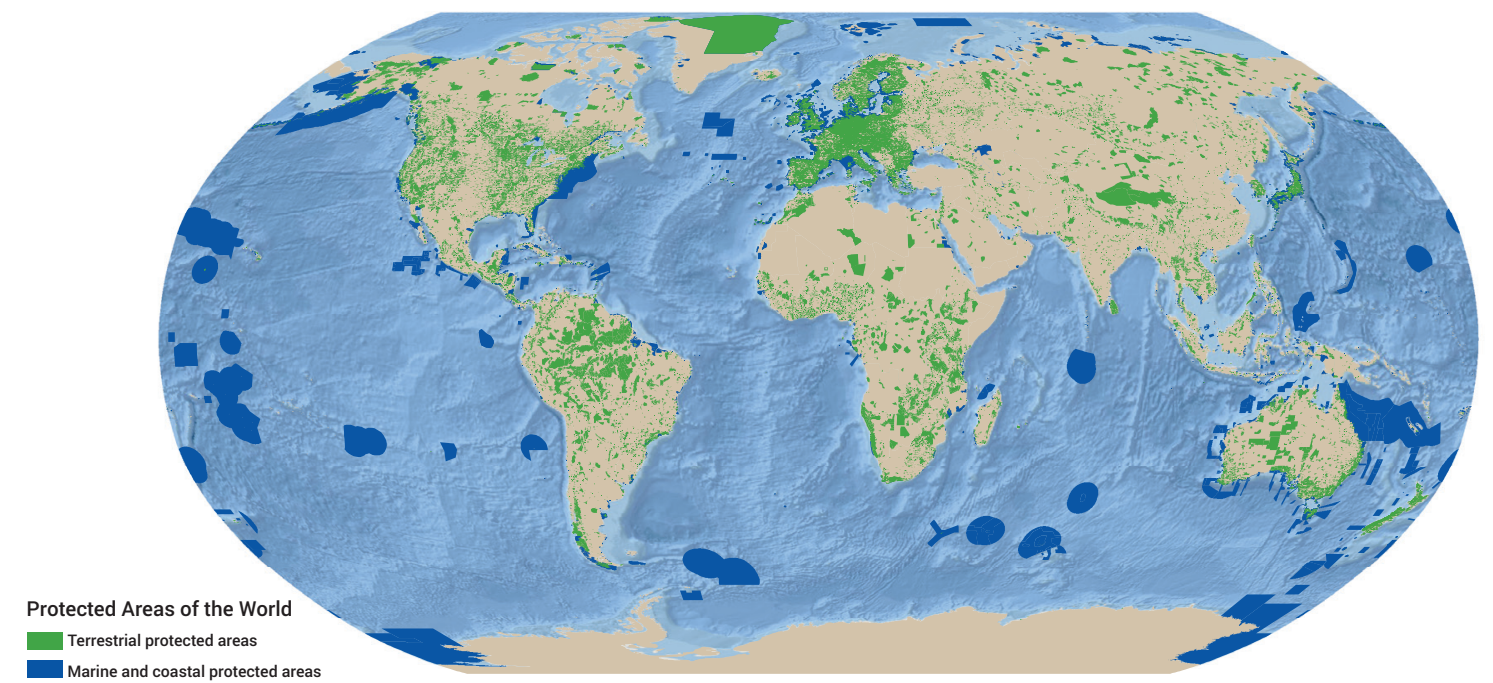

Source: United Nations Environment Programme-World Conservation Monitoring Centre, International Union for Conservation of Nature and National Geographic Society (2018). 
Transnational agreements on trade in waste and hazardous waste dumping have had measurable positive effects. $\{14.2 .2\}$

With regard to the effectiveness of goal-setting, the Millennium Development Goals (MDGs) mobilized action at the local and global levels (established but incomplete). For example, the MDG mandates are credited with 1.5 billion people gaining access to basic drinking water services between 2000 and 2015 (well established). The MDGs coincided with accelerated progress on poverty eradication, health and education, but there was less progress on nutrition and on access to water and sanitation services. $\{2.5 .2\}$ MDG implementation efforts also resulted in the increased capacity of countries to produce and use statistics on poverty, education, health, gender, environment and governance. $\{3.3\}$

International agreements have successfully addressed a number of specific chemicals, but new chemical risks are emerging (established but incomplete). Environmental concentrations of POPs have been reduced in Europe, North America, Asia and the Pacific, and the Arctic. There are two legally binding international treaties on POPs: the Stockholm Convention on POPs and the Protocol to the regional United Nations Economic Commission for Europe [UNECE] Convention on LongRange Transboundary Air Pollution [CLRTAP] on POPs). $\{5.2 .2\}$

Among economic measures, green bonds and other environmentally beneficial financial instruments are increasingly used to promote green investment (established, but incomplete). New financial instruments, both State-regulated and privately initiated (or hybrid), can provide a platform for successful investment in green technologies or biodiversity conservation. Developed countries and countries in the global South (e.g. China and Nigeria) are using green bonds. Norway has successfully used subsidies and tolls to encourage use of electric vehicles. Creative state-subsidized projects such as the "Working for Water" programme in South Africa (which employs low-skilled people, women, youth and people with disabilities to remove invasive plants) can have both environmental and social benefits. $\{13.2 .4,13.2 .3\}$

Environmental sustainability may also be promoted through cultural practices or the creation of new institutions (established but incomplete). For example, in many places women farmers have traditionally played a crucial role in protecting seeds. Seeds may also be conserved in gene banks. There were 1,750 gene banks in the world in 2010, which maintained an estimated
7.4 million accessions (both plants and animals). The Svalbard Global Seed Vault in Norway, established in 2008, plays a significant global role in protecting seeds and plant genetic diversity. As of 2018, it held over 1 million duplicate seed samples deposited by gene banks worldwide. $\{13.2 .4$, Table 13.5\}

Significant progress has been made around the world in implementing education for sustainable development (ESD) in all educational sectors (well established). However, upscaling ESD is still needed if it is to be integrated into educational systems globally. Education will contribute to achieving the SDGs and mainstreaming environmental sustainability as a shared social value, but robust policy action is needed to eliminate economic and gender barriers to accessing education. $\{4.2 .4\}$

Many of the achievements in environmental policies and protection are generating economic and social co-benefits. Although evidence is mixed on the extent to which economic trade-offs from a transition to a low-carbon and green economy will emerge, overall it is likely that the net effects would at least not be negative. \{Chapter 22, ExecSum, Figure 22.9\}

\section{Investing in environmentally sound sectors can} generate substantial returns (established but incomplete). For example, depending on the scenario used, at the global level the health benefits of reduced air pollution have been estimated to be 1.4 to 2.5 times greater than the costs of mitigation. The highest benefit-to-cost ratio is for the emissions reduction strategy to reach the $2^{\circ} \mathrm{C}$ target of the Paris Agreement: global health savings are estimated at US\$ 54.1 trillion, more than twice the global policy costs of US\$22.1 trillion. Under all the scenarios examined, the countries likely to see the highest health savings from improved emission reduction measures are China and India. The costs of implementing climate mitigation policies in these two countries would be fully compensated by health savings under most scenarios. The added costs of pursuing a $1.5^{\circ} \mathrm{C}$ instead of a $2^{\circ} \mathrm{C}$ target could generate substantial benefits (about US\$ 0.3-2.3 trillion and about US\$ 3.3-8.4 for China and India, respectively). In the EU and the United States, modelling suggests that the health savings would be high but would not fully compensate for the costs. \{Chapter 24, ExecSum, Box 24.1\}

Gender equality has a multiplier effect in advancing sustainable development, including environmental protection and social justice (well established). All aspects of the environment, including drivers, pressures, impacts, perceptions, policies and responses, are shaped by gender relations and mutually constituted 
considerations of gender norms and responsibilities. Bringing gender perspectives to bear on environmental policies and governance, especially through supporting participation, leadership and decision-making by women, ensures that new and different questions and viewpoints (as well as gender-disaggregated data) are integrated into environmental assessments (well established), and that public resources are more likely to be directed towards human development priorities and investments. $\{4.2 .3\}$

\section{Achieving the SDGs will require the benefits of sustainable economic development to be used predominantly to increase the capabilities and opportunities of those with the least advantages (well established). For example, educating girls, improving the status and opportunities of women, and enabling poor people to achieve full participation in society would strengthen sustainable economic growth and development, as well as reducing alienation and conflicts. \{Chapter 2, ExecSum, 2.5.2, 2.5.3\}}

While environmental protection policies may threaten jobs in polluting sectors, they can also generate more and cleaner jobs in other sectors (established but incomplete). Phasing out polluting sectors (e.g. fossil fuel production and fossil-fuelled transport) leads to loss of employment and livelihoods in those sectors, but there will be new job opportunities in sectors that replace them such as renewable energy and waste management/recycling. \{1.3.1\} Furthermore, while 1.2 billion jobs in agriculture, fisheries and forestry depend on a stable and healthy environment, that is also true of many jobs in tourism, pharmaceuticals and other industries which depend on natural environmental processes. $\{17.6\}$ The overall health of the planet has profound implications for employment and livelihoods (see Table 4.1)

\section{A global shift to a circular economy based on increased resource efficiency could contribute to economic growth and human well-being, with reduced environmental pressures and impacts. (established but incomplete) Key considerations in implementing a circular economy are reducing and rethinking resource use, and the pursuit of longevity, renewability, reusability, reparability, replaceability and upgradability for resources and products that are used. This would have}

Table 4.1: A healthy or unhealthy planet: employment and livelihoods (E\&L)

\begin{tabular}{|c|c|c|c|c|c|}
\hline & Healthy Planet provides E\&L (+) & Unhealthy planet affects E\&L (+/-) & Policy: E\&L lost (-) & Policy: E\&L gained (+) & Ref. \\
\hline$\cdot \frac{1}{<}$ & Good health to enable work & $\begin{array}{l}\text { Air pollution is the No. } 1 \\
\text { environmental cause of ill-health } \\
\text { ( } 25 \% \text { of disease) affecting E\&L }\end{array}$ & $\begin{array}{l}\text { Jobs lost in fossil } \\
\text { fuel/polluting } \\
\text { industries }\end{array}$ & $\begin{array}{l}\text { Jobs gained: } 8.1 \text { million } \\
\text { jobs in renewables } \\
\text { globally in } 2016 \text { and } \\
\text { could grow to } 20 \text { million } \\
\text { by } 2030\end{array}$ & 1 \\
\hline $\begin{array}{l}\frac{\lambda}{\omega} \\
\frac{2}{2} \\
\frac{2}{0} \\
\frac{0}{\infty}\end{array}$ & Supports life including agriculture & Affects agriculture/life & Could affect farmers & $\begin{array}{l}\text { Managing Natura } 2000 \\
\text { sites creates 180,000 } \\
\text { jobs }\end{array}$ & 2 \\
\hline 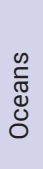 & $\begin{array}{l}\text { Small-scale fisheries provide } 80 \\
\text { per cent of jobs ( } 58-120 \text { million } \\
\text { livelihoods) with } 10 \text { million jobs in } \\
\text { larger-scale fishing; jobs in marine- } \\
\text { based tourism }\end{array}$ & Affects fisheries and tourism & $\begin{array}{l}\text { Marine parks' policies } \\
\text { could affect fishing } \\
\text { jobs }\end{array}$ & $\begin{array}{l}\text { Policies based } \\
\text { on involving local } \\
\text { communities could } \\
\text { create jobs }\end{array}$ & 3 \\
\hline 믐 & $\begin{array}{l}\text { Agriculture employs }>30 \text { per cent of } \\
\text { the workforce, mostly in developing } \\
\text { countries where } 40 \text { per cent of } \\
\text { smallholders are women; } 2.5 \text { billion } \\
\text { people directly depend on land, } \\
\text { including } 1-1.5 \text { billion on forests; } \\
13 \text { millioon people are employed } \\
\text { in the formal forest sector plus } \\
40-60 \text { million in informal small and } \\
\text { medium-sized forest operations }\end{array}$ & $\begin{array}{l}\text { Land degradation affects } 3.2 \text { billion } \\
\text { people }\end{array}$ & $\begin{array}{l}\text { Land grabbing } \\
\text { affects smallholders }\end{array}$ & $\begin{array}{l}\text { Community-based } \\
\text { agriculture and forest } \\
\text { policy and recognition } \\
\text { of tenure rights could } \\
\text { protect jobs and the } \\
\text { environment }\end{array}$ & 4 \\
\hline 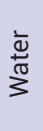 & $\begin{array}{l}\text { Those employed in agriculture/ } \\
\text { industry and the service sector } \\
\text { depend on water for their } \\
\text { livelihoods }\end{array}$ & $\begin{array}{l}\text { Water pollution affects health and } \\
\text { the ability to work; water scarcity } \\
\text { affects agricultural income }\end{array}$ & - & $\begin{array}{l}\text { Recycling water can } \\
\text { create jobs }\end{array}$ & 5 \\
\hline
\end{tabular}

References: FAO 2005; Wei, Patadia and Kammen 2010; Agrawal et al. 2013; Bourguignon 2015; FAO 2015; FAO 2016a; FAO 2016 b ; ILO 2016; Garrett-Peltier 2017; IRENA 2017; OECD 2017; United States Department of Energy 2017; Yihdego, Salem and Pudza 2017; FAO 2018; Renewable Energy Policy Network for the 21st Century [REN21] 2018;). \{GEO-6, Table 7.1\}. 
substantial co-benefits for greenhouse gas abatement and waste and pollution minimization. $\{17.6\}$

Participatory approaches can help decision makers
identify and pursue innovative solutions to achieve sustainability (established, but incomplete). Participatory and grassroots approaches provide a useful landscape of initiatives and aspirational visions, pathways and solutions from stakeholders to achieve the SDGs. This includes inclusive innovation, in which power and decision-making are relatively decentralized and externalities are internalized. These approaches also highlight gaps and blind spots in distributional equity and in responsibilities for (and capabilities to) address global environmental problems and their solutions. Participatory approaches can help deliver context-relevant solutions. For example, decentralized renewable energy generation and microgrids fit well in many bottom-up sustainable visions that challenge traditionally modelled large-scale, centralized energy transitions. \{Chapter 23, ExecSum, 23.6\}

\section{Effective environmental policies require diverse policy instruments and governance approaches as part of well-designed policy mixes (well established, but incomplete). Too often the policy mix contains misaligned or conflicting policies that undermine policy effectiveness, especially where economic and sectoral policies are not aligned with environmental goals. Formulating effective environmental policy would benefit from new forms of data collection, including social disaggregation of data and information, and integrating citizen science and indigenous knowledge pathways into formal environmental assessments and policies. \{Chapter 21, ExecSum\}}

Despite success stories, policy actions overall are not adequate to address the severity of environmental problems (well established). Urgent action on an unprecedented scale is needed to protect human health and the environment, maintain the current and future integrity of global ecosystems, and reverse some of the most significant environmental damage that has already taken place. Key actions will include reducing air, land and water pollution, land degradation, and biodiversity loss; improving management of water and other resources; climate change mitigation and adaptation; implementing greater resource efficiency; adopting decarbonization, decoupling and detoxification approaches; and preventing and managing acute risk and disasters. All these actions require more ambitious and effective policies, including for sustainable consumption and production, greater resource efficiency and improved resource management, integrated ecosystem management, and integrated waste management and prevention. \{Chapter 22; SPM Section 2$\}$

\subsection{Addressing specific drivers through policy innovation}

Mainstreaming environmental considerations into the drivers of environmental problems, including social and economic decisions at all levels and in all sectors, is of vital importance. In line with the SDGs, GEO-6 demonstrates that environmental issues are best addressed along with related economic and social issues, taking into consideration synergies and tradeoffs among different goals and targets, especially equity and gender dimensions (well established). The integration of environmental concerns needs to be improved at the local, national, regional and global levels, including broad coordination among policy areas. More ambitious and effectively implemented environmental policies are necessary, but are not sufficient in themselves to meet sustainable development objectives. At the same time as ensuring sustainable sources of financing for sustainable development and aligning financing flows with environmental priorities, institutional capacities need to be strengthened and scientific information taken into account in order to improve environmental management. Strong commitment by all stakeholders and partnerships, and international cooperation, would greatly facilitate the realization of environmental goals. \{Chapters 22, 23, 24; SPM Section 2\}

Current policies that address the underlying drivers of environmental unsustainability are unevenly developed; climate change and urbanization appear to receive more policy attention currently than other drivers (uncertain). Policies that address mutually interdependent drivers and their cumulative effects on the environment are difficult to design, implement and assess. Climate change is being addressed through United Nations Framework Convention on Climate Change (UNFCCC) activities. The environmental impacts of urbanization are receiving increasing attention in local and national policies. However, in all cases effective policy implementation lags far behind. Global policymakers increasingly understand the nature of the drivers of large-scale environmental change, but local and national policies for effective intervention are weakly developed and enforced. $\{11.3,21.3 .1\}$

There is considerable expert disagreement (and contradictory evidence) concerning the extent to which population growth places pressure on the environment. (well established) If efforts to reduce population growth are integrated into environmental and social policies, 
they should be based on respect for the rights of women and for their choices. A rights-based approach that places reproductive control in the hands of women may reduce rates of population growth. Most importantly, however, this approach will enhance gender equality and women's empowerment. Government-supported population policies could consider providing access to modern contraceptive methods (Figure 4.2); enhancing access to voluntary family planning and other reproductive health services; investing in women's education; removing barriers to women's participation in the labour force; creating legal regimes to dismantle discriminatory practices associated with traditional patriarchal practices of male control over women, including male violence against women; and enabling women's full participation in national and local-level decision-making and policy-setting positions. $\{2.3 .4\}$

Inequality (North-South, international, rich-poor, or rural-urban) and increasing climate vulnerability are major drivers of migratory patterns (unresolved). Closing international welfare gaps, and promoting economic growth in the least developed countries, will moderate migratory flows. Migration within countries is driven by inequalities, especially between rural and urban areas, leading to rapid and sometimes environmentally unmanageable urbanization. While adequate developmental support for rural areas helps moderate such pressures, this support should be designed and carried out in environmentally sustainable forms. "Business as usual" growth programmes for rural and poor regions may solve one set of social problems while exacerbating existing environmental problems and creating new ones. Innovative support for climaterelated adaptation and resilience is urgently needed. $\{2.3 .6\}$

Coupled with efficiency improvements, the transition to low-carbon energy sources has been accelerating globally in the last decade although it remains insufficient to achieve the $2^{\circ} \mathrm{C}$ global average

\section{Figure 4.2: Contraceptive prevalence and total fertility}

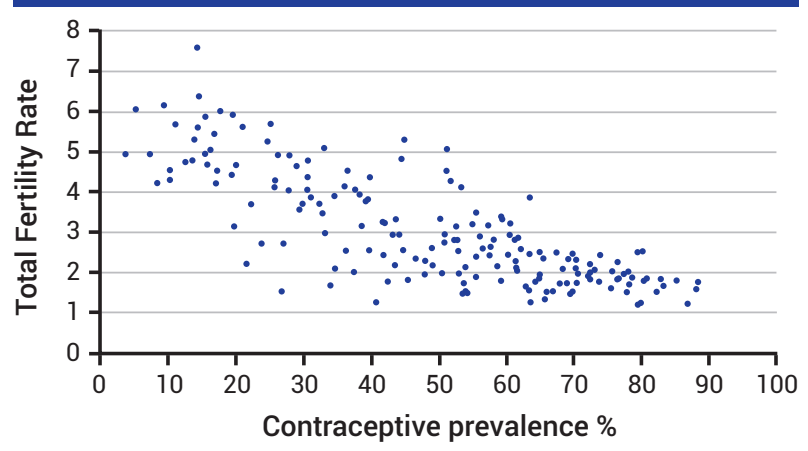

Source: Own elaboration based on World Bank (2017). temperature goal of the Paris Agreement, let alone the $1.5^{\circ} \mathrm{C}$ aspiration (well established). Understanding this should stimulate greater ambition and bolder action in the area of technology innovation and encouraging behaviour change. However, providing billions of poorer people with access to electricity and other modern energy sources remains a challenge. $\{4.4 .2\}$

Decoupling environmental degradation and resource use from economic growth (and its associated production and consumption patterns) will be required in order to achieve the SDGs (well established). Partial decoupling of environmental pressures and economic growth can already be observed for some impacts and resources in certain countries. Further decoupling will require the scaling-up of existing sustainable practices and more fundamental transitions in the ways we produce, consume and dispose of goods and materials across society. These transitions are likely to be more effective if supported by long-term, comprehensive, science-based targets that provide an objective basis for future directions and actions. $\{2.5 .1$; SPM, p. 6\} More fundamental changes may also be needed. This view is consistent with the intention to keep the GEO-6 theme of "Healthy Planet, Healthy People" central to our understanding of genuine progress. $\{4.2 .1\}$

What appears to be a decoupling of growth in one sector or territory can mask continuing environmental and social impacts elsewhere (established but incomplete). Examples are the substitution of one non-renewable resource for another (e.g. the cleaner energy systems that replace fossil fuels but still require non-renewable resources) and shifting costs and environmental burdens (e.g. importing resource-intensive consumer goods from developing countries). $\{17.6 .1\}$

\subsection{Thematic responses}

\section{GEO-6 found evidence of effective policies through} the systematic assessment of a range of case studies from all world regions. For each thematic area of GEO-6, five or six case studies were analysed for policy effectiveness against 12 or more criteria identified from the literature. In addition, the effectiveness of environmental policies was scrutinized by analysing policy-sensitive indicators. Effectiveness criteria for the case studies included goal achievement, unintended effects, baseline, coherence/synergy, co-benefits, equity, enabling/constraining factors, cost-effectiveness, timeframe, ease of implementation, acceptability, stakeholder involvement, intergenerational impacts, and transboundary impacts. GEO-6 authors participated in an expert elicitation ranking the effectiveness of 29 case studies. None of the case studies ranked 
high on all effectiveness criteria, despite being selected because they represented generally accepted successful policies. The most common failings were absence of a baseline; lack of compensation for negatively impacted groups; the impacts of external factors; inadequate consideration of institutional capacity for implementation; and lack of stakeholder involvement in policy design. This suggests areas in which policymakers could make improvements in the future. The shortcomings identified in the case studies were mirrored in the indicators: throughout the thematic areas, environmental policies are not effectively addressing the drivers of environmental changes. $\{18.1\}$

\subsubsection{Air}

There is no single global agreement addressing air pollution, but instead a patchwork of regional intergovernmental agreements and initiatives focused on public-private partnerships (established but incomplete). Global MEAs that have linkages to air pollution include those targeting climate change (UNFCCC), stratospheric ozone depletion (the Vienna Convention and the Montreal Protocol), mercury (the
Minamata Convention) and POPs (the Stockholm Convention). Several regional MEAs and bilateral agreements exist. One of the oldest regional MEAs is the 1979 Convention on Long-Range Transboundary Air Pollution (CLRTAP) negotiated under the UNECE (Figure 4.3). Considerable progress on policy cooperation, monitoring and modelling, emissions control and reporting, and ecosystem recovery has been achieved under the eight legally binding CLRTAP Protocols. \{Chapter 12\}

Under the UNFCCC, the 2015 Paris Agreement sets out a global action plan to put the world on track to avoid dangerous climate change by limiting global average temperature to well below $2^{\circ} \mathrm{C}$. Currently the "nationally determined contributions" of emissions presented in Paris in $\mathbf{2 0 1 5}$ collectively constitute only one-third of the mitigation efforts required to stay well below $2^{\circ} \mathrm{C}$ (well established). $\{2.2,2.7,4.2 .1,5.2,5.3 .4\}$ To remain well below the $2^{\circ} \mathrm{C}$ goal, global emissions need to drop by between 40 and 70 per cent between 2010 and 2050, falling to net zero by 2070. $\{2.7 .4\}$ The IPCC produces regular assessments of climate change

Figure 4.3: Groupings of selected regional multilateral air pollution agreements
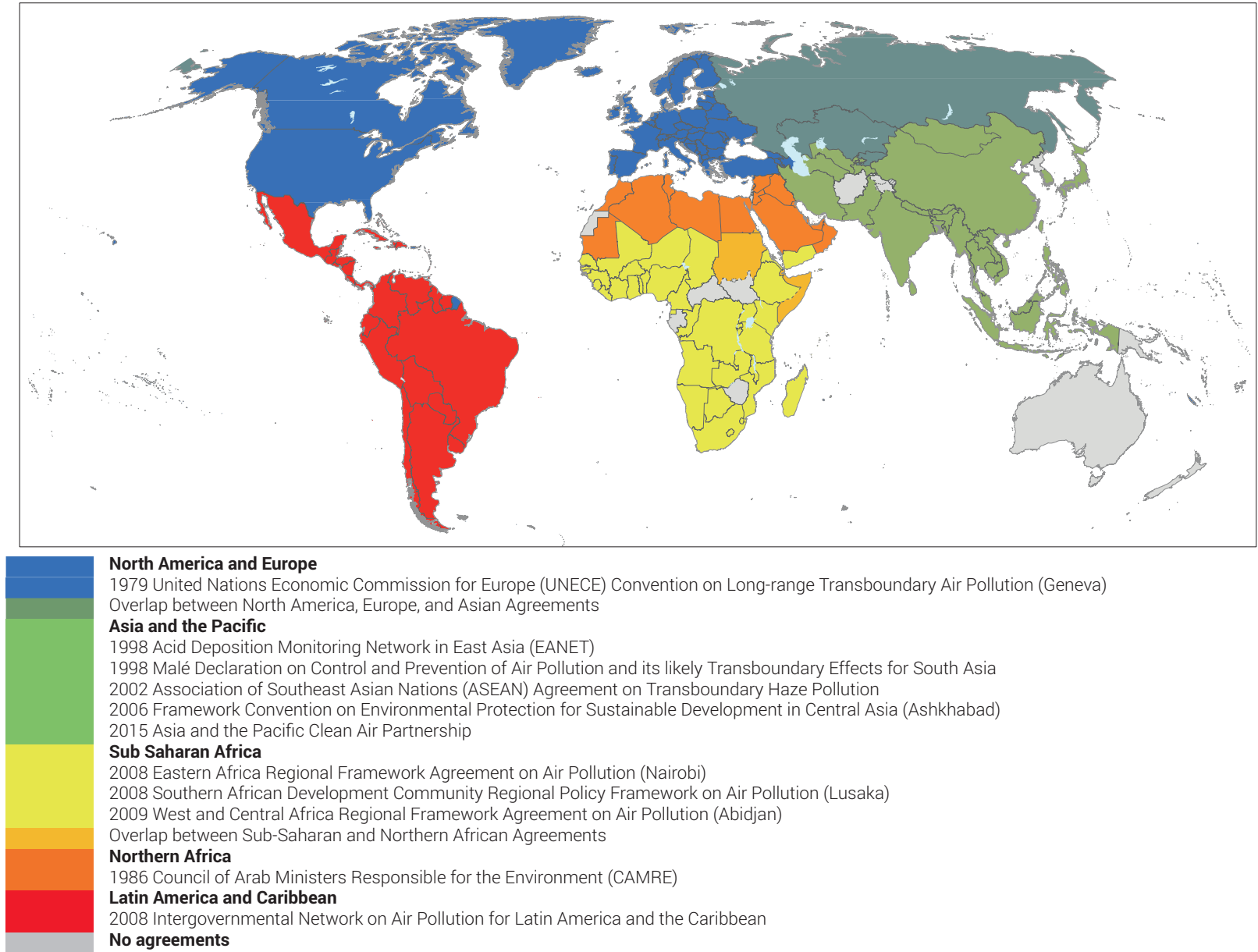

North America and Europe

1979 United Nations Economic Commission for Europe (UNECE) Convention on Long-range Transboundary Air Pollution (Geneva)

Overlap between North America, Europe, and Asian Agreements

Asia and the Pacific

1998 Acid Deposition Monitoring Network in East Asia (EANET)

1998 Malé Declaration on Control and Prevention of Air Pollution and its likely Transboundary Effects for South Asia

2002 Association of Southeast Asian Nations (ASEAN) Agreement on Transboundary Haze Pollution

2006 Framework Convention on Environmental Protection for Sustainable Development in Central Asia (Ashkhabad)

2015 Asia and the Pacific Clean Air Partnership

Sub Saharan Africa

2008 Eastern Africa Regional Framework Agreement on Air Pollution (Nairobi)

2008 Southern African Development Community Regional Policy Framework on Air Pollution (Lusaka)

2009 West and Central Africa Regional Framework Agreement on Air Pollution (Abidjan)

Overlap between Sub-Saharan and Northern African Agreements

Northern Africa

1986 Council of Arab Ministers Responsible for the Environment (CAMRE)

Latin America and Caribbean

2008 Intergovernmental Network on Air Pollution for Latin America and the Caribbean

No agreements

Source: UNEP (2019a, p. 131). 
and its impacts. \{SPM, p. 7$\}$ The latest IPCC $1.5^{\circ} \mathrm{C}$ special report indicates that the scale of the required reduction in emissions is unprecedented and extremely challenging. Increasingly, there is international financial support for climate change adaptation and resiliencebuilding measures at national and local levels (Figure 4.4) although the amount is considerably less than is needed.

International banks increasingly finance air pollution related projects (well established). Institutions including the World Bank, the Asian Development Bank, the African Development Bank, the Global Environment Facility and the Green Climate Fund play major roles in project funding for air pollution mitigation at national levels. Financial assistance and cooperative implementation of control measures can have clear and demonstrable effects in decreasing local emissions in the short term, although increasing long-term national and global positive impacts on planetary health requires successful control measures to be replicated and scaled up. $\{$ Chapter 12$\}$

Many public-private initiatives complement State action on air pollution. They include the Partnership for Clean Fuels and Vehicles, the Global Alliance for Clean Cookstoves \{Chapter 12, 12.2.3\}, the Global Research Alliance on Agricultural GHGs, and the Climate and Clean Air Coalition for the Reduction of Short-Lived Climate Pollutants (CCAC). \{Chapter 12\}

Air pollution has been widely subject to regulatory approaches, including the use of emissions and technology standards, which have been successful in addressing some pollution sources (established but incomplete). Planning regimes establish ambient targets (e.g. concentration standards, total pollutant loads, or a change in global mean temperature) and emissions budgets (or ceilings). Clusters of policies are then developed and implemented to meet targets or budgets. Progress is monitored and, if necessary, additional policies are developed or existing policies are revised. \{Chapter 12, ExecSum\} In addition to ambient standards, emissions standards and performance standards for specific industrial processes, equipment or products are critical, especially in the transport sector. \{ Chapter 12 , ExecSum, 12.2.1, 12.2.2\}

Air policy has also used economic incentives (e.g. subsidies, tax credits, loans or price guarantees) and disincentives (e.g. fees or taxes) in existing markets, or created new markets for rights or commodities that had previously not been traded (e.g. emissions reduction credits or renewable energy credits) in order to influence lifestyle and technology choices (well established). All these types of market interventions have been used to some extent to mitigate air pollution, climate change, ODS or PBTs. While market interventions do not directly reduce emissions or ambient concentrations, they provide regulated businesses and individuals with flexibility and can create incentives to improve performance and lower costs. \{Chapter 12$\}$

Infrastructural and technological innovation and transfer can improve energy efficiency in manufacturing sectors (including mining) and are key to reducing emissions. Energy efficiency can be improved through

Figure 4.4: Climate finance for adaptation
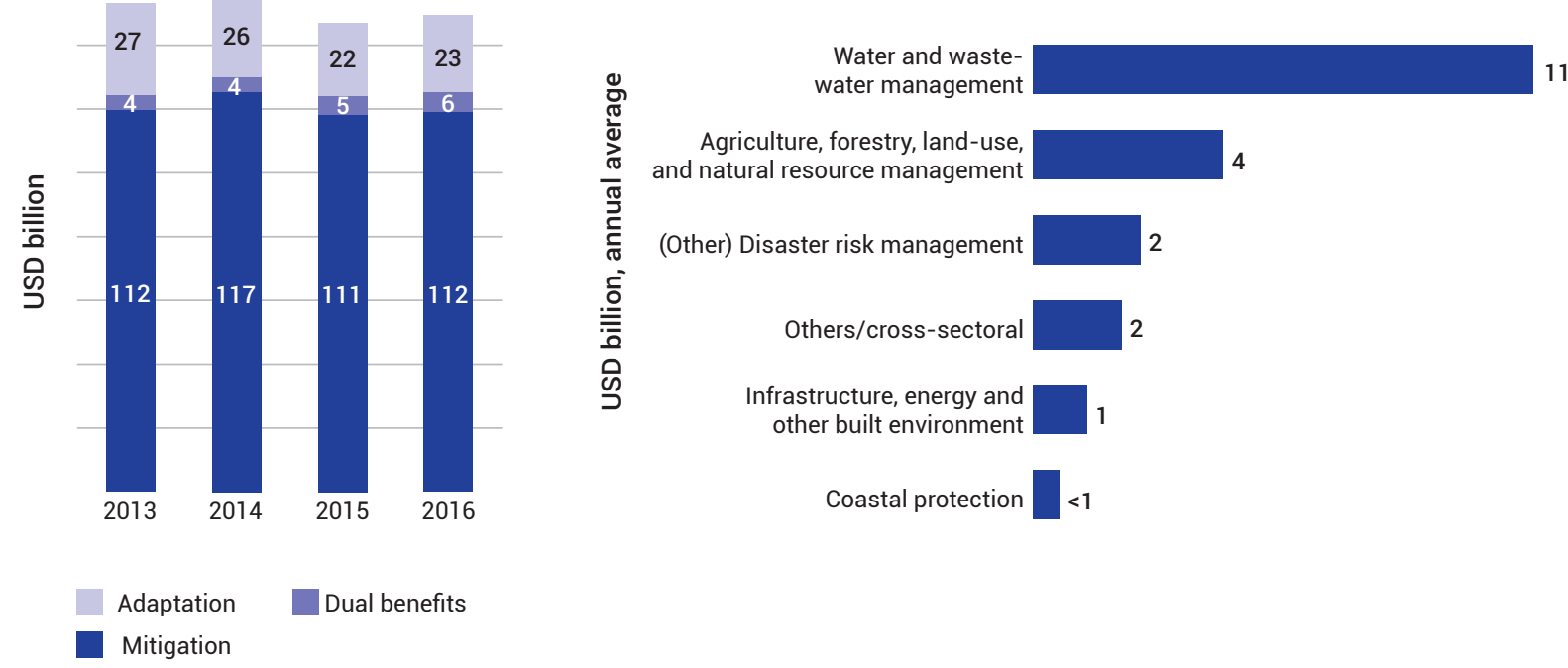

Note: Climate finance comes from the public sector

Source: Buchner et al. (2017). 
approaches such as cleaner brick kiln technology, piloted in Asia and Latin America; cleaner technologies to reduce or eliminate mercury use piloted in several countries; and Perform-Achieve-Trade schemes for energy intensive industry in India. $\{5.2 .3\}$

\section{Information and behavioural/ persuasive policies have been used to promote lifestyle changes in order to reduce either emissions or exposure to harmful levels of air pollution by providing the public with better information. (well established) This is in line with improved understanding of the hazards and risks of exposure to air pollution in recent years, although the importance of public education with respect to air pollution control was raised many years ago. These approaches need to reach a threshold level of awareness and recognition across their target populations before they have much effect on consumption and other emissions-generating behaviour, or on impacts (exposure-related behaviour). However, once this threshold is reached, citizens can begin to expect and demand such information. Moreover, increasing awareness of the sources and impacts of pollution may increase public demand for cleaner air, lower-emitting products and services, and more stringent policies. \{Chapter 12$\}$}

\subsubsection{Biodiversity}

The Convention on Biological Diversity (CBD) is the key global convention on biodiversity; this has been manifested through instruments such as the Strategic Plan for Biodiversity 2011-2020 (encompassing the Aichi targets), the Cartagena Protocol on Biosafety, and the Nagoya Protocol on Access to Genetic Resources and the Fair and Equitable Sharing of Benefits Arising from their Utilization. A new Strategic Plan for 20202030 is being developed. There is also a patchwork of other multilateral and bilateral intergovernmental agreements, as well as private sector biodiversity investment initiatives (well established). During the last 10 years, awareness about the loss of biodiversity has risen significantly in international discourse on health and economic policy. A number of internationally agreed biodiversity-related conventions, treaties and platforms have framed considerable global efforts to protect and conserve biodiversity, including areas beyond national jurisdictions (established but incomplete). These have been important in obtaining increased responses at the national level. \{Chapter 6, ExecSum, 6.7.1, 13.1\}

The CBD is supported by scientific assessments. In 2012 the IPBES was established to strengthen the science-policy interface for biodiversity and ecosystem services/nature's contributions to people for the conservation and sustainable use of biodiversity, long- term human well-being and sustainable development $\{6.1\}$. IPBES released a landmark global assessment in 2019 (IPBES 2019).

Conservation of biological diversity is mainly undertaken through management of protected areas. (well established) Both the establishment and effective management of protected areas constitute an important response to the need to conserve biodiversity, as reflected in Aichi Biodiversity Target 11 of the Strategic Plan for Biodiversity 2011-2020. The International Union for the Conservation of Nature and Natural Resources [IUCN] defines a protected area as "a clearly defined geographical space, recognized, dedicated and managed, through legal or other effective means, to achieve the long-term conservation of nature with associated ecosystem services and cultural values" (IUCN 2018). \{6.6.3\}

In addition to State collaboration, the private sector is increasingly engaged in biodiversity protection. (well established) The Natural Capital Coalition, which evolved in 2014 from The Economics of Ecosystems and Biodiversity (TEEB) global initiative, is an international collaboration that aims to mainstream natural capital approaches in the public and private sectors. \{Annex 13-2\} Gene banks also draw on international investment support. Tax breaks for green infrastructure, conservation agreements, carbon offsets, green fiscal policies and green bonds, and private- and third-sector investment are response tools available to policymakers to support investments in biodiversity conservation. Green bonds are one of the fastest growing fixedincome market segments, with US\$ 81 billion in 2016. Green bonds can be used strategically by governments and corporations to tap international capital in order to support investment in biodiversity conservation; they can also provide a platform for interactions between financial and investment policymaking, which are institutionally separate in some countries. \{Chapter 13, ExecSum, 13.2.4; Annex 13-2\}

Biodiversity has often been addressed at national levels through policy measures regulating endangered species and national land-based and marine parks. While the creation of protected areas is often effective in preserving species, such zones can present issues of legitimacy, equity and sustainability for local communities. Integrating the views of local stakeholders during the decision-making and implementation phases is often key to the success of policies. \{13.2.2\} At the same time, the rise in trade of endangered species (including through the Internet) raises questions about the effective monitoring and implementation of such policy instruments. The $\mathrm{CBD}$ requires parties to submit 
National Biodiversity Strategies and Action Plans (NBSAPs) that reflect national policies and articulate the challenges they face in moving forward, although these plans have been unevenly produced. $\{13.3\}$

National biodiversity conservation efforts are reflected in the NBSAPs submitted to the CBD (well established). A NBSAP is a national policy expression of globally agreed biodiversity conservation goals. Biodiversity has also been increasingly inculcated in a wider range of national policy and planning tools. Examples include assigning monetary values to nature's contributions to people; the UN System of Environmental-Economic Accounting; and the OneHealth approach, which promotes collaboration to address the drivers of human disease, biodiversity loss and ecosystem degradation. \{Chapter 6, 5.6

\section{Biodiversity conservation has used economic} incentives and market-based instruments to shape the behaviour of people and their relationship with the environment. (well established) This approach is based on the assumption that economic incentives can address market externalities through facilitating pro-conservation behaviour, disincentivizing negative behaviour, and compensating stakeholders who are negatively affected by biodiversity conservation. Economic instruments are able to address scale mismatches in biodiversity conservation, for example where the benefits of conservation are felt at a regional or national scale while the cost is borne by local communities on a smaller scale. $\{13.1\}$ Such instruments include payment for ecosystem services and Reducing Emissions from Deforestation and forest Degradation, plus the sustainable management of forests, and the conservation and enhancement of forest carbon stocks (REDD+). \{13.2.3\} Market and other mechanisms have also been used to reduce over-fishing including eco-certification, individual transferable quotas in British Columbia $\{14.2 .4\}$ and traditional user rights in Chile. $\{14.2 .3\}$

Traditional knowledge held by indigenous peoples and local communities (IPLCs) is increasingly understood to be a valuable resource for biodiversity conservation, environmental assessment and sustainable development (well established). This is demonstrated by the increase in the number of studies and discussions on traditional knowledge and its inclusion in global policy agreements. Nevertheless, the ability of poor and indigenous people to conserve biodiversity and protect associated ecosystems would be enhanced by secure tenure rights. $\{13.2 .2, \mathrm{SPM}, 2.2 .4,8.5 .3\}$

To address current and future challenges including climate change, research suggests that the best approaches may be characterized by the coordination of modern science and technology with traditional knowledge. While cooperation between local and global communities and knowledge systems has proven successful for the health of individuals and the planet, challenges remain. Traditionally based knowledge is often gender-differentiated, and successful efforts to amplify and include traditional knowledge will only be successful if both women and men are part of collaborations. $\{13.1$; Chapter $25,25.2 .3\}$

The ex situ conservation of genetic material in gene banks, aided by the use of new genomic tools, has become an integral part of conserving genetic diversity (well established). Advances in technology allow cheaper and faster genome sequencing. This has accelerated the rate of sequencing of crops and their wild relatives, although genetic data for most wild species is lacking. The ex situ conservation of genetic material in gene banks (or seed banks) is practised at local and national levels. $\{6.4 .1,13.2 .4\}$

Financial resources at levels much higher than at present are needed in order to conserve biodiversity. Sources of financing for investment in biodiversity can come from multiple sources (SCBD 2012), including core national biodiversity funding sources, national government financing, international flows of Official Development Assistance, and multilateral funding. Meeting the 2020 Aichi Biodiversity Targets would provide monetary and non-monetary gains that far outweigh the costs of achieving these goals. \{Chapter 13\}

Policies and mechanisms aiming to support innovative measures can strengthen biodiversity conservation. (well established) For example, arrangements such as community-based protected areas (e.g. Locally Managed Marine Areas) are needed to supplement national protected areas for conserving biodiversity in the long term. $\{13.1$; Exec Sum, Chapter 13\} During the last few decades there has been a shift away from protected areas that exclude humans towards more people-centred or community-based conservation and integrated landscape management. Communities are the major players in decision-making in indigenous and community conserved territories and areas (ICCAs). ICCAs play a key role in conserving traditional ecological knowledge, as well as cultures and languages, which are often inextricably linked to biodiversity conservation. $\{13.4 .2\}$

There is a close connection between biodiversity loss, human health, poverty, and uneven access to natural resources (well established). Biodiverse systems can facilitate human health and equity. To reverse 
trajectories of biodiversity loss and degradation and meet globally agreed targets, biodiversity policies need to advance equity and not place disproportionate burdens on already-vulnerable populations or on future generations. \{Exec Sum Chapter 13\}

Despite unprecedented efforts to protect ecosystems and biodiversity on community, national and international scales, there has been no slowing or reversal of the decline in global biodiversity (well established). While there has been significant progress towards meeting some components of the Aichi Biodiversity Targets of the Strategic Plan for Biodiversity 2011-2020, in most cases this progress has not been sufficient to achieve the targets for 2020. \{13.4, 21.3.2\}

\subsubsection{Oceans and Coasts}

No single global agreement addresses all ocean issues, but there is a patchwork of regional and intergovernmental agreements and initiatives including public-private partnerships (well established). Policy coherence and integration are important in addressing the cumulative impacts of local and regional threats to support the resilience of marine ecosystems (e.g. coral reefs) to climate change and land-based pollution (inconclusive). However, without international policies to curb carbon emissions, the effectiveness of resiliencebased management is likely to be very limited given the limited capacity of marine species to adapt to warmer ocean waters (well established). \{Chapter 14, ExecSum, 14.2.1; Exec Sum\}

Marine governance instruments include the $\mathbf{1 9 8 2}$ United Nations Convention on the Law of the Sea, which sets out the legal framework regulating all activities in the oceans and the follow-up Agreement on the Conservation and Management of Straddling Fish Stocks and Highly Migratory Fish Stocks. (well established). These overarching agreements are supported by several treaties addressing the pollution of marine areas. Increasingly, there is a policy of regional cooperation to address regional maritime problems including marine litter. The Regional Seas Programme is one of UNEP's main activities addressing coastal and marine environmental issues. This programme illustrates regional cooperation approaches to coastal and marine management. It focuses on engaging neighbouring countries in regional action plans to tackle problems in shared marine environments. $\{14.2 .5\}$

International non-governmental organizations (NGOs) are collaborating to protect coral reefs (well established). There has been considerable interest in resilience-based approaches to coral reef management. For example, the Coral Triangle Initiative (an intergovernmental and NGO activity involving Indonesia, Malaysia, Papua New Guinea, the Philippines and Timor-Leste) incorporates resilience principles and multi-issue management. The International Union for Conservation of Nature (IUCN) has adopted an agenda for action on coral reefs, climate change and resilience that urges the development of policies to support resource-based management at national and international levels. $\{14.2 .1\}$

National oceans-related policies rely on diverse regulatory measures, with varying success (established but incomplete). Planning instruments such as integrated coastal zone management and marine spatial planning have often been successfully used. Territorial Use Rights for Fishing (TURF) programmes are a good fit for fisheries with relatively sedentary stocks, high exclusionary potential, and governments keen to devolve costly management and enforcement functions (well established). Individual transferable quotas (ITQs) work best in the case of relatively high-value stocks when supported by strong, independent, scientifically set quotas and strong monitoring, control and surveillance. The regulation of access and resource use rights may be successful when effective enforcement and compliance mechanisms are in place (well established). \{Exec Sum Chapter 14, 14.2.3\}

Resilience-based management of coral reefs is an emerging concept in a context of very limited alternatives, given that the basic cause of coral stress and death is the increasing level of atmospheric $\mathrm{CO}_{2}$. Resilience-based management refers to strategic policy interventions at local and regional levels that support ecological resilience (i.e. the capacity to resist disturbances and to recover from these disturbances). It is believed to help offset, to some extent, the increasing effects of climate change although individual national efforts are not proportionate to the global scale of the problem. $\{14.2 .1\}$

Problems involving numerous ocean and coastal activities, sectors and sources (e.g. marine litter) require policies involving comprehensive and coordinated measures (established but incomplete). When such problems involve multiple jurisdictions, governance approaches to engage neighbouring countries (e.g. the Regional Seas Programme) may be appropriate. $\{14.2 .2\}$

Lack of standardization makes it difficult to track progress towards marine conservation (well established). In the case of beach litter, used as an indicator of litter in the marine environment, the lack of standardization 
and compatibility between methods used and results obtained in various bottom-up projects makes it difficult to reach an overall assessment of the status of marine litter over large geographical areas. $\{14.3 .2\}$

\subsubsection{Land and Soil}

Land areas generally fall under national jurisdiction. (well established) There is no single global agreement addressing land related pollution, but again there is a patchwork of international, regional and national intergovernmental agreements and initiatives focused on land-related issues. \{Chapter 15, ExecSum\}

The 1994 United Nations Convention to Combat Desertification (UNCCD) is the principal international legally binding agreement that associates sustainable land management with environment and development. It addresses dry sub-humid, semiarid and arid land areas, where some of the most vulnerable ecosystems and people are found. $\{15.2 .2\}$

Other treaties regulate various aspects of landrelated challenges. For example, the Stockholm Convention regulates production and use of POPs, while the Basel and Rotterdam Conventions regulate hazardous waste movements between countries and imports of hazardous chemicals. $\{15.2 .3\}$

Sustainable land management is a major instrument for climate change mitigation because it increases carbon sequestration in the soil (well established). This is why land and soil policy gained increasing international recognition during climate change negotiations at the 21 st Conference of the Parties to the UNFCCC (COP 21) in Paris in 2015, when the "4 per 1000 Initiative" was launched by the Government of France. This initiative promotes enhancement of soil quality, carbon sequestration and soil conservation through improved agricultural practices that mitigate climate change. \{Chapter 15, ExecSum, $15.3 .1,15.4\}$

There is no legally binding global convention on the protection of forests. (well established) Attempts to agree such a convention at the Rio Earth Summit in 1992 resulted only in the Non-Legally Binding Authoritative Statement of Principles for a Global Consensus on the Management, Conservation and Sustainable Development of All Types of Forests. This document makes several recommendations for conservation and sustainable development of forests. \{Chapter 15\}
United Nations voluntary declarations are a first step towards protecting minority rights and responsibilities with respect to land. The rights of indigenous peoples to their lands and territories are explicitly mentioned in the UN Declaration on the Rights of Indigenous People (Articles 25 and 26). FAO's Voluntary Guidelines on the Responsible Governance of Tenure (VGGT) also seek to improve the governance of land tenure (public, private communal, indigenous, customary and informal). $\{25.2 .3\}$

Land protection policies differ among countries and regions, from barely existent to well defined (established but incomplete). Often national policies and programmes that address socioeconomic development (e.g. economic incentives for agricultural, bioenergy and urban development) have overlooked land degradation side-effects. If economic growth is not decoupled from environmental degradation, local policies aimed at sustainable use and management of land will not succeed. \{Chapter 15, ExecSum\}

Land protection policies have built on sustainable land management strategies and used a diversity of regulatory mechanisms, including land tenure/ ownership rules, spatial planning, economic incentives, and standards for the use and disposal of pesticides and other chemicals. The success of any strategy to combat desertification depends on the implementation of sustainable land and water management practices that are adapted to specific local geo-biophysical and socioeconomic situations. Well-managed soils slow down the process of land degradation, regulate the water cycle, safeguard biodiversity, conserve landscape multifunctionality, and improve the provision of ecosystem services. Economic incentives for sustainable land management include subsidies for farmers who plant trees or undertake other soil conservation measures. \{Chapter 15\}

Tenure-secure indigenous lands generate benefits worth billions of dollars in the form of carbon sequestration, reduced pollution, clean water, erosion control and many other local, regional and global ecosystem services (established but incomplete). Current tenure rules and practices present critical challenges. There is increasing evidence, however, of local indigenous communities successfully managing and conserving their lands. The benefits of tenuresecure lands are likely to outweigh the costs in most 
countries (Figure 4.5) (established but incomplete). $\{8.5 .3\}$

Education is critical in land policy. (established but incomplete) The provision of education and extension services, and knowledge about the complementary approaches of no-tillage agriculture and conservation agriculture, can help combat soil erosion, optimize crop production, promote soil health by keeping soil organic matter and nutrients in place, sequester carbon, and improve water and air quality. With these practices, yields tend to be lower than with conventional agriculture at least during the first few years. With time, this gap can narrow. $\{15.2 .4\}$

Land-use planning, sustainable use of land resources, and sustainable land management can balance production with environmental protection (well established). Sustainable intensification practices attempt to integrate increasing crop yields with the maintenance of soil fertility and improvements in water-use efficiency. Annually, US\$ 75.6 trillion can be gained through implementing global policies that enable sustainable land management. Among many other

Figure 4.5: Benefits of tenure-secure lands outweigh the costs in three Latin American countries

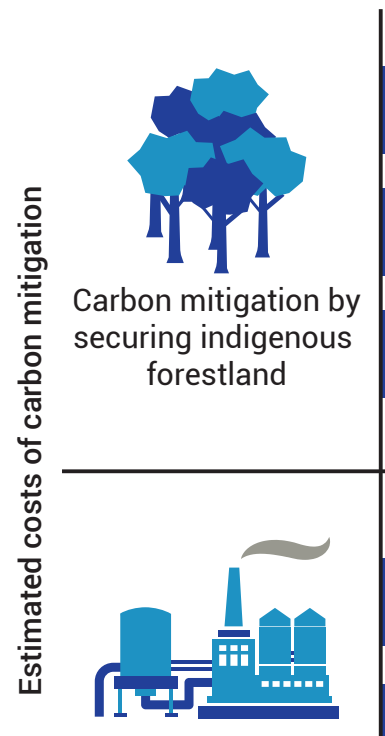

Carbon capture and storage
Bolivia $\$ 2.04-3.66 / \mathrm{tCO}_{2}$

Brazil \$8.74-11.88/tCO

Colombia $\$ 4.75-7.26 / \mathrm{tCO}_{2}$

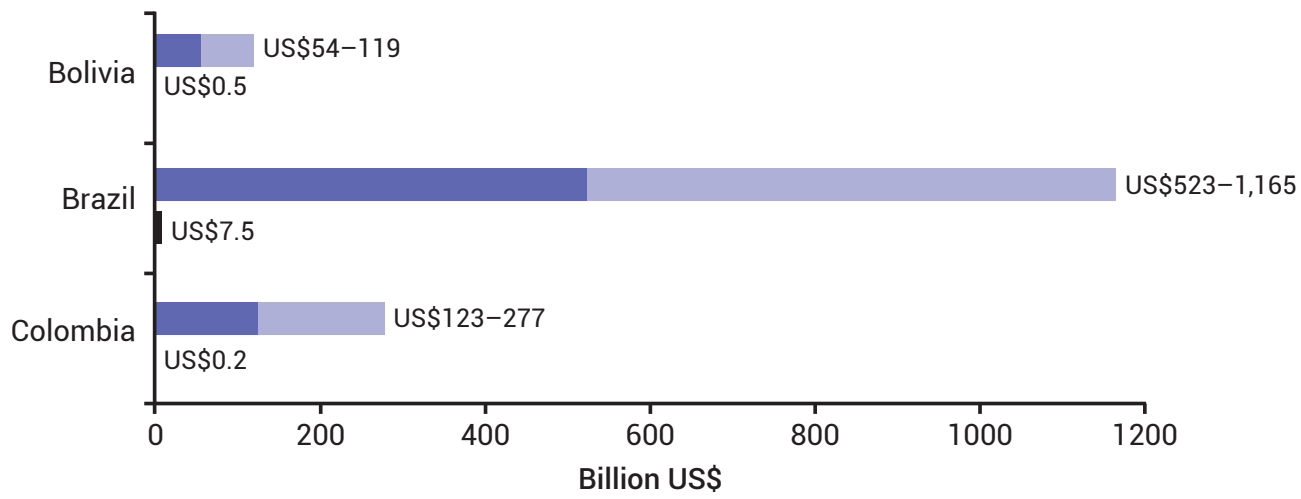

Total ecosystem-service benefits (lower bound estimate)

Total ecosystem-service benefits (upper bound estimate)

Tenure-security establishment costs

Source: Ding et al. (2016). 
sustainable land management practices, conservation agriculture that includes zero tillage is a good example of a practice that maintains land quality, enhances soil carbon sequestration, mitigates climate change, protects biodiversity and sustains productivity. However, policies, economic analysis, science and farming incentives are needed to support the implementation of such practices, especially by small landowners and above all those in developing countries. \{Chapter 15, ExecSum, 15.2.4\}

Land management, restoration and policies need to be tailored to local conditions (well established). Successful policy implementation depends on a number of factors that provide an integrated landscape approach well matched to socioeconomic and natural characteristics, supported by good governance and good levels of stakeholder engagement. \{ Chapter 15, ExecSum, 15.2.4, 15.2.5\}

\subsubsection{Freshwater}

There is no single international agreement addressing all freshwater issues - many intergovernmental agreements (bilateral and multilateral) and publicprivate initiatives address issues related to freshwater and to transboundary river basins (well established). By 2007 there were 250 freshwater treaties, with 30 additional treaties being entered into every decade, mostly focusing on water quality and the environment. For transboundary rivers, more comprehensive agreements have been developed over the past few decades. Forty-three countries are Parties to the UNECE Water Convention, which entered into force in 1996. The UN Watercourses Convention, which entered into force in 2014, has 36 Parties. However, greater global attention is merited to lakes, reservoirs, wetlands and other lentic (standing) water systems, both because of the vast quantities of freshwater they contain (more than $90 \%$ of the liquid freshwater on the surface of Earth), and the wide range of life-supporting ecosystem services they provide to humanity. $\{16.3 .3\}$

Globally important wetlands are protected under the 1971 Ramsar Convention on Wetlands. By 2019, 170 member states had designated 2,341 "Wetlands of International Importance" (known as "Ramsar sites")

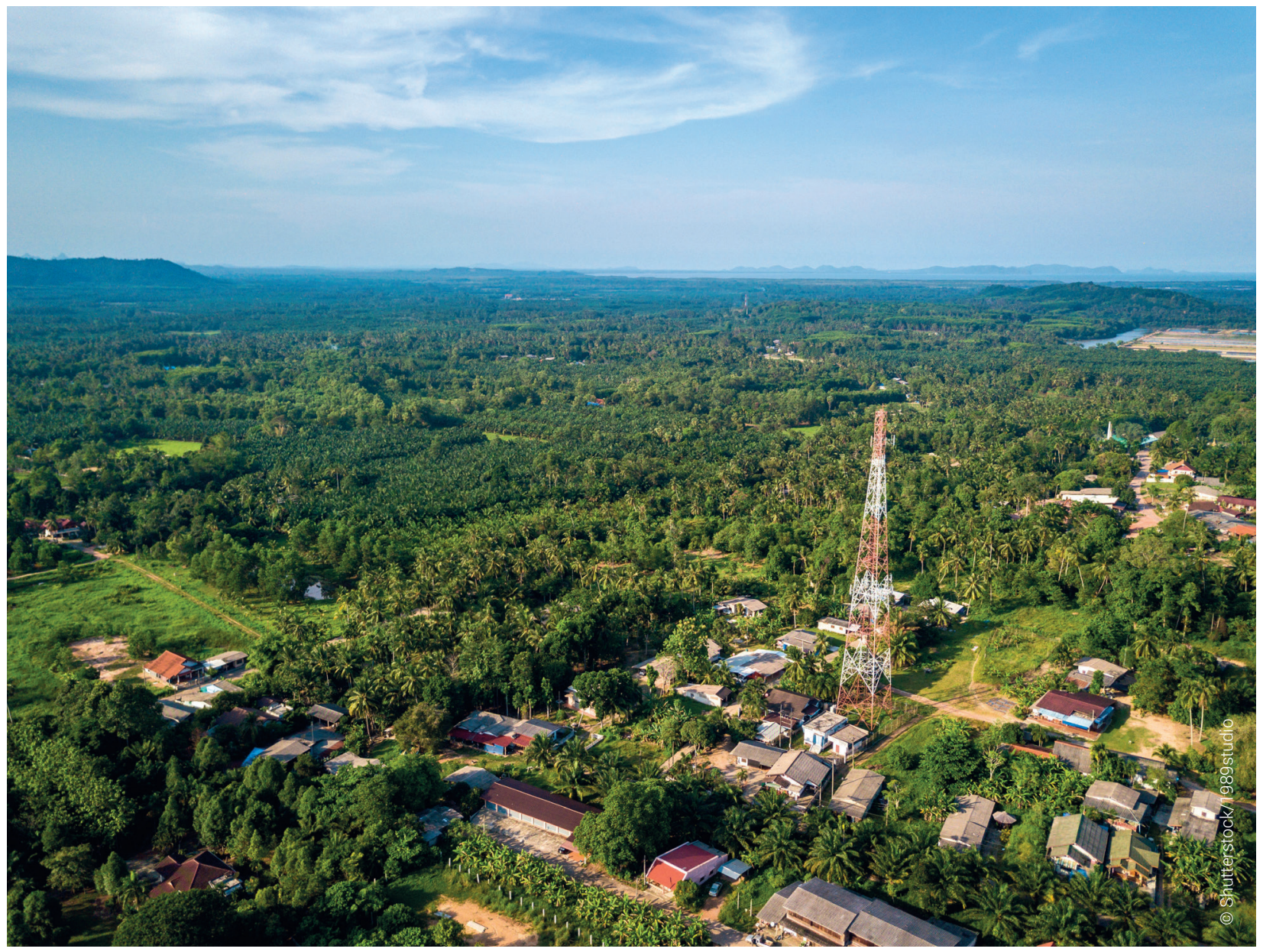


protecting 252 million hectares, an increase of 81 million hectares since 2000 (Figure 4.6). \{Annex 6.1\}

There are non-legally binding agreements which recognize the human rights to water and sanitation services. The right to water includes considerations of sufficiency, safety, acceptability, physical accessibility and affordability for personal and domestic uses. The development of the MDGs introduced a partial human rights approach to water while maintaining the notion of water as an economic good: there are clearly tensions between these approaches. A growing number of countries now formally recognize this human right, following a General Assembly Resolution. The 2014 Global Analysis and Assessment of Sanitation and Drinking-Water reported that 70 out of 94 countries recognized the right to water. SDG 6, which has six targets with their indicators, aims to "ensure availability and sustainable management of water and sanitation for all". National constitutions and legislation in which the right to water is recognized need to be supported by policy instruments that target financing and budgeting. Lack of financing is one of the primary obstacles to realizing the rights to water and sanitation. Water pricing,

\section{Figure 4.6: Ramsar sites designated, by year and region}

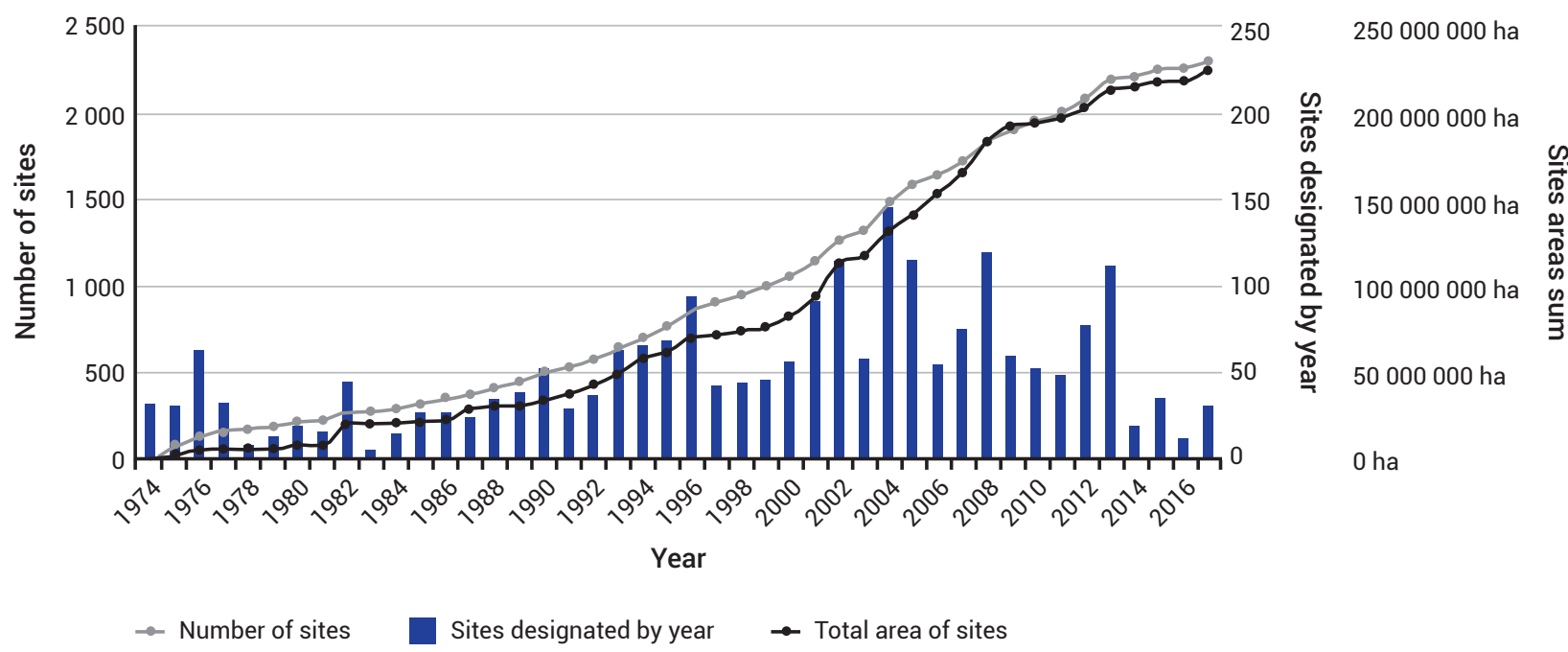

Total area of sites

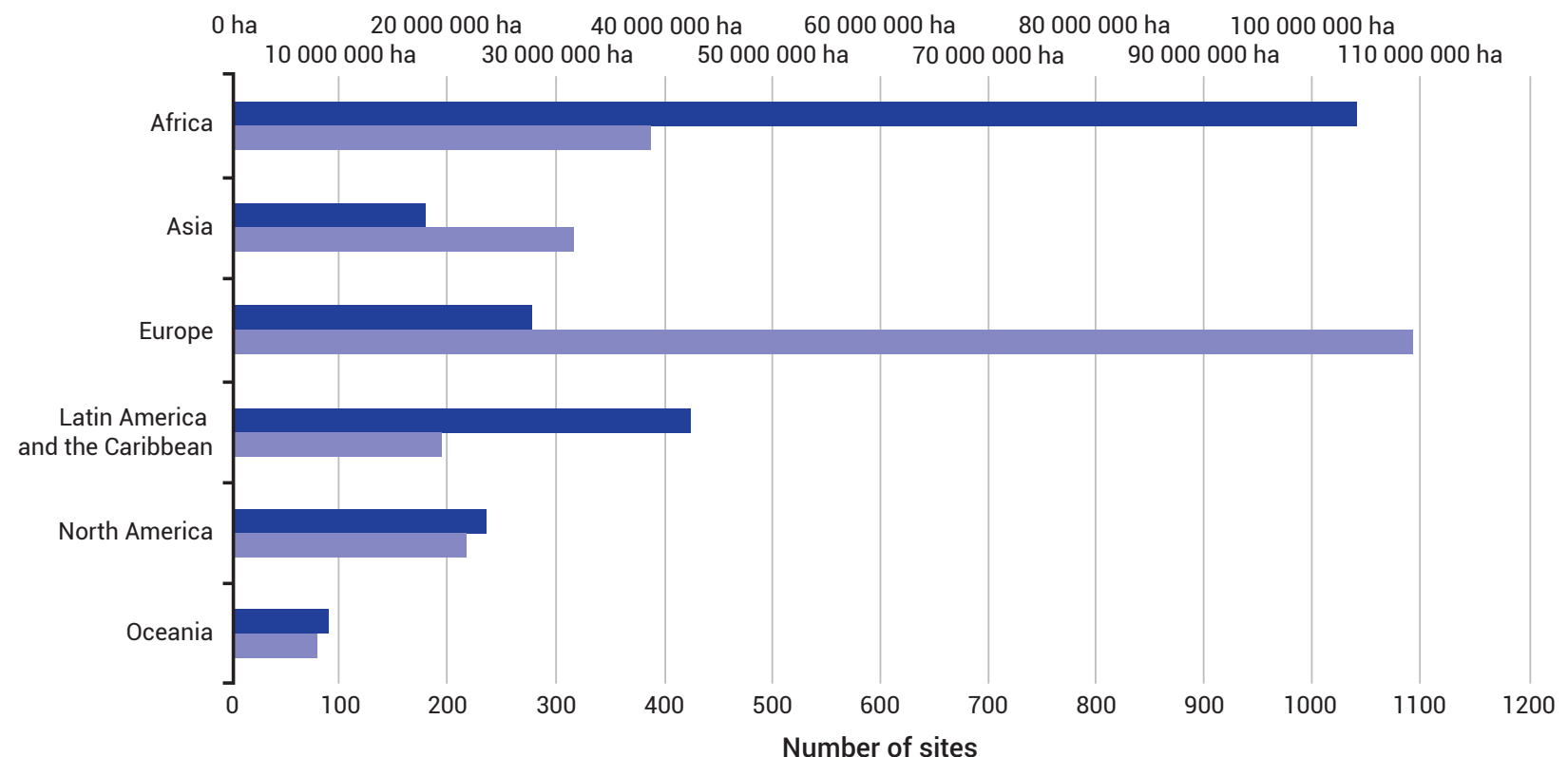

Number of sites Total area of sites 
if it is efficient, includes all the economic costs required to provide water. It underscores that the right to water does not necessarily call for free water provision. $\{16.2 .4\}$

International and transboundary river basin organizations (RBOs) are critical for transboundary treaty implementation. (established but incomplete) In general, the main functions of RBOs are (i) data gathering, monitoring and regulation; (ii) river basin planning; and (iii) development of infrastructure and facilities. \{Chapter 16\} Many RBOs are guided by Integrated Water Resource Management (IWRM) principles that seek to achieve efficiency, equity and ecological sustainability while addressing water quality and quantity issues. Examples of international RBOs include the International Commissions for the Protection of the Rhine and the Danube in Europe; the Mekong River Commission in Asia; the Senegal River Basin Development Organization, the Niger Basin Authority, the Zambezi Watercourse Commission, the Limpopo Watercourse Commission and the Nile Basin Initiative in Africa; the La Plata Basin Treaty in Latin America; and the Great Lakes Commission in North America. Such organizations could usefully be extended to cover international and transboundary lake and reservoir basins. $\{16.2 .1\}$

\section{Voluntary reporting on water use and pollution in the mining sector is becoming critically important. Mining operations typically use vast amounts of water. Governments, companies and communities have recognized the fundamental need for efficient management of water resource-related risks by the mining industry. The main voluntary protocol for sustainability reporting is the Global Reporting Initiative (GRI), which began in 1997 as a coalition of government, community and corporate stakeholders, and aimed to make sustainability reporting as commonplace and important as corporate reporting. The current GRI standard includes a wide range of indicators across social, economic, environmental and local-community health aspects. It was designed to be used not only by the mining sector, but by any company or organization. $\{16.2 .5\}$}

\footnotetext{
National water policy increasingly uses and implements integrated water resources management (IWRM) in a participatory process, based on intersectoral coordination and greater engagement of non-governmental actors. An integrated management approach should consider both flowing rivers/streams (lotic water systems) and standing lakes/ wetlands (lentic water systems) in developing basin management plans. Managing lentic water systems also requires recognition of their unique characteristics, compared to flowing water systems (e.g., long water retention time; integrating
}

nature; non-linear responses). Integrated Lake Basin Management (ILBM) provides a means of addressing these unique features within basin management plans via integration of institutional responsibilities, policy directions, stakeholder participation, scientific and traditional knowledge, technical possibilities and funding prospects. Collaborative efforts are required to involve the private sector and NGOs, or local governments and citizens. Stakeholder engagement is a long-term process that requires investment in supporting stakeholder relationships. Institutions should be designed to enable inputs to decision-making from these relationships, rather than treating them on an ad hoc basis. Devolution of water governance requires supporting investments, capacity-building and sustained long-term awarenessraising efforts. Fusion of ILBM within IWRM would provide a comprehensive and effective management approach. \{Chapter 16, ExecSum, 16.1, 16.2.1, 16.2.2, 16.2.5\}

While policy approaches become further integrated and complex, there is an ongoing need to address basic environmental clean-up and the reversal of damaging legacies. Even in developed economies regulation, technical fixes and investments are required in order to continually improve water use practices and prevent the degradation of water quality. $\{16.1\}$ However, new policies may be needed to change the direction of trends in water use. $\{$ Chapter 16, ExecSum, 16.6.1\}

\section{Efficient water use requires water-sensitive urban design of water infrastructure, including conjunctive surface and groundwater development and promotion of managed aquifer recharge (well established). Together with investment in wastewater treatment and recycling, these approaches support water quantity and quality management. They also promote drought risk reduction and resilient urban water supplies. At the same time, the provision of drinking water supply and sanitation services to all (as well as leakage control from bulk water supplies) are still challenges in many cities of the world. $\{9.9\}$}

Promoting water-use efficiency, water recycling, water reclamation and rainwater harvesting is increasingly important to ensure more equitable water allocation for different users and uses, thereby facilitating human water security (well established). Circular approaches such as reusing water within recycle loops help to reduce water withdrawals, as well as protecting ecosystem health. More sustainable management and better monitoring of surface and groundwater is urgently needed. $\{9.4 .2,9.9 .5\}$

For effective management, an entire watershed or river basin needs to be considered holistically as an integrated socio-ecological system (well established). This entails 
managing water resources across agriculture, forestry, cities, industry, domestic and commercial uses within the context of the ecosystems remaining in the basin. MEAs governing water resources and water-related ecosystem management and climate change support embedding IWRM in laws, including national and local legislation, regulations and institutions. However, in some regions there is limited capacity to implement IWRM at the institutional or individual level. \{9.9.3\}

Monitoring, modelling and managing aquifer systems and flux exchanges with freshwater and ecosystems at local, national and transboundary scales are essential in order to implement sound aquifer and integrated water resources management (well established). For example, salinization of aquifers resulting from subsidence in river deltas is a complex issue for coastal agriculture and urbanization, whereas saline intrusion into coastal aquifers can be controlled through managed aquifer recharge. \{Chapter 9, ExecSum, 9.9\}
Evidence-based risk management is essential to promote cooperative water governance and build trust with and among stakeholders (well established). The availability of open, transparent data is important in implementing multilateral environmental agreements and water-related conventions; supporting a bottom-up inclusive and informed stakeholder engagement; and facilitating uptake of scientific knowledge and best practice. Citizen science, and decentralization of decisions to impacted communities, are increasingly being included in good water governance, along with support for multinational cooperation in transboundary basin and aquifer management. The use of remote sensing and smart technologies to map available water resources (and abstractions and quality), combined with ground-truthing of data, mapping demographic and land-use changes, can be used for early warning of water scarcity as well as disaster risk reduction. $\{9.4 .4\}$

Figure 4.7: SDGs targeted by the total workshop seeds and the total Climate CoLab proposals

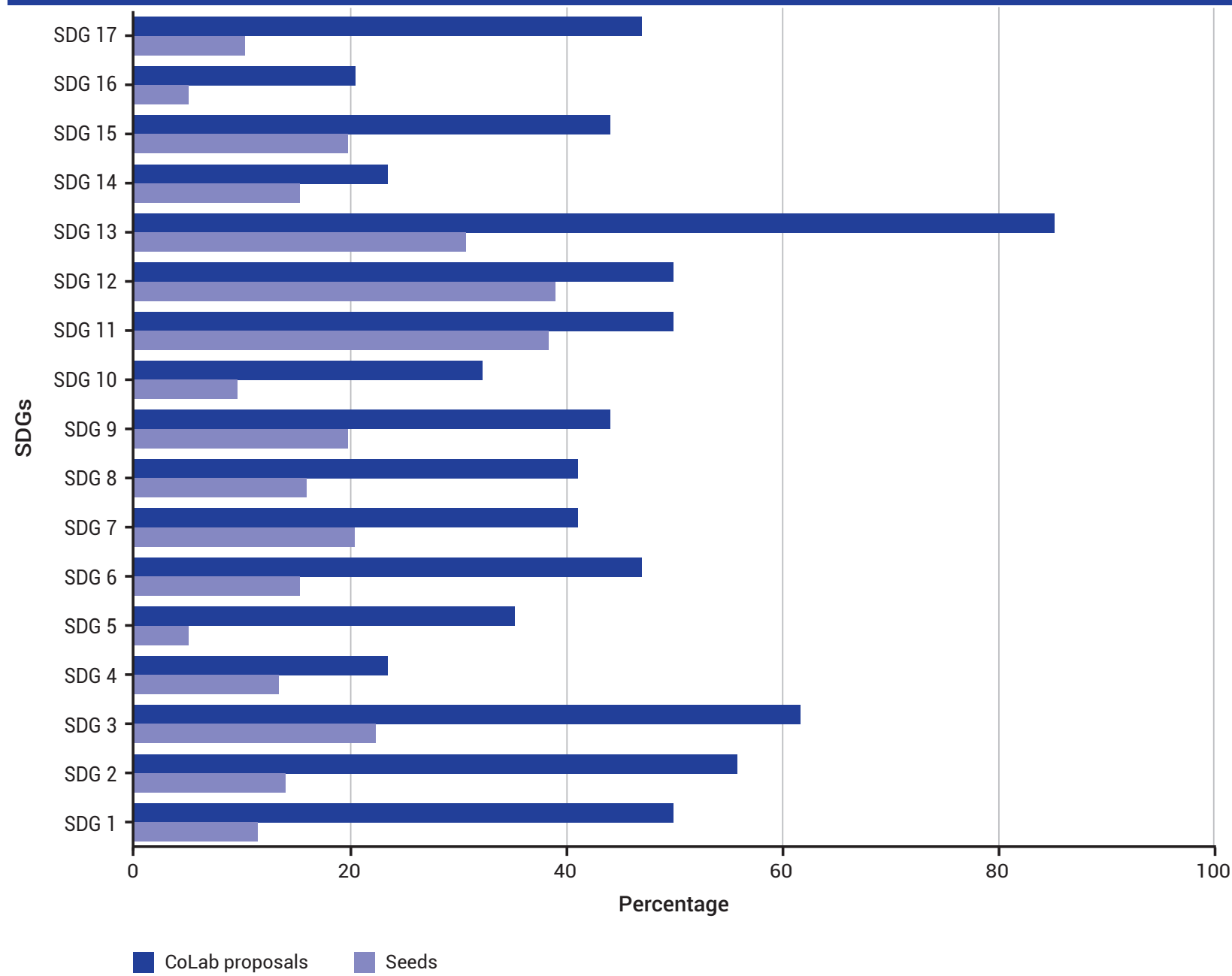

Source: UNEP (2019, p. 556) 


\subsection{Bottom-up action}

The need to consider the primary evidence (as opposed to scholarly publications) regarding the contributions of bottom-up initiatives is being recognized formally in global assessments (unresolved). This demonstrates both political commitment to bottom-up implementation and the potential to achieve environmental goals, such as decarbonization by 2050. $\{23.4\}$ In the Fifth Assessment Report of the IPCC, Chapter 12 on human settlements, infrastructure and spatial planning acknowledged the role of local actors in global climate mitigation. The 2016 Emissions Gap Report included, for the first time, an assessment of multiple studies that quantified the additional contribution of local actors to mitigation. This analysis found that subnational and non-State actors could reduce emissions by as much as $10.0 \mathrm{Gt}$ of $\mathrm{CO}_{2}$ in 2020 compared with 2015 . These cuts would help narrow the 12-14 Gt gap in 2030 between emissions cuts by national governments and the amount that global scenarios tell us is needed to avoid a $2^{\circ} \mathrm{C}$ increase in global average temperature although the latest IPCC report emphasizes the need for global action to meet the $1.5^{\circ} \mathrm{C}$ target (IPCC 2018). $\{23.4\}$
Several approaches for bottom-up futures identify local practices and small-scale sustainability initiatives at varying geographic levels and across sectors (unresolved). At the global level, the Seeds of Good Anthropocenes and Climate CoLab projects are examples of such initiatives. Other "seeds" (small-scale sustainability initiatives) were identified at workshops held at the time as some of the GEO- 6 authors' meetings. The Seeds of Good Anthropocenes project is developing a collection of local, social, technological, economic, ecological and socio-ecological initiatives to help envision positive environmental futures.

Climate CoLab is an online platform where anyone can submit and discuss climate change solutions. While the Seeds of Good Anthropocenes project focuses on identifying and investigating local initiatives, Climate CoLab focuses primarily on initiative identification, development and evaluation through a crowdsourcing mechanism. \{23.4\} The workshop seeds and Climate CoLab proposals identified for GEO-6 targeted each of the 17 SDGs to varying extents. Figure 4.7 highlights the range of SDGs found in the analysis. Figure $\mathbf{4 . 8}$ shows the types of issues addressed. In the case of the workshop seeds, SDG 12 (responsible consumption and production) and SDG 11 (sustainable cities and

Figure 4.8: Total number of workshop seeds and Climate CoLab proposals addressing each intervention in the agriculture, food, land and biodiversity cluster (seeds and proposals are double counted when they meet multiple measures)

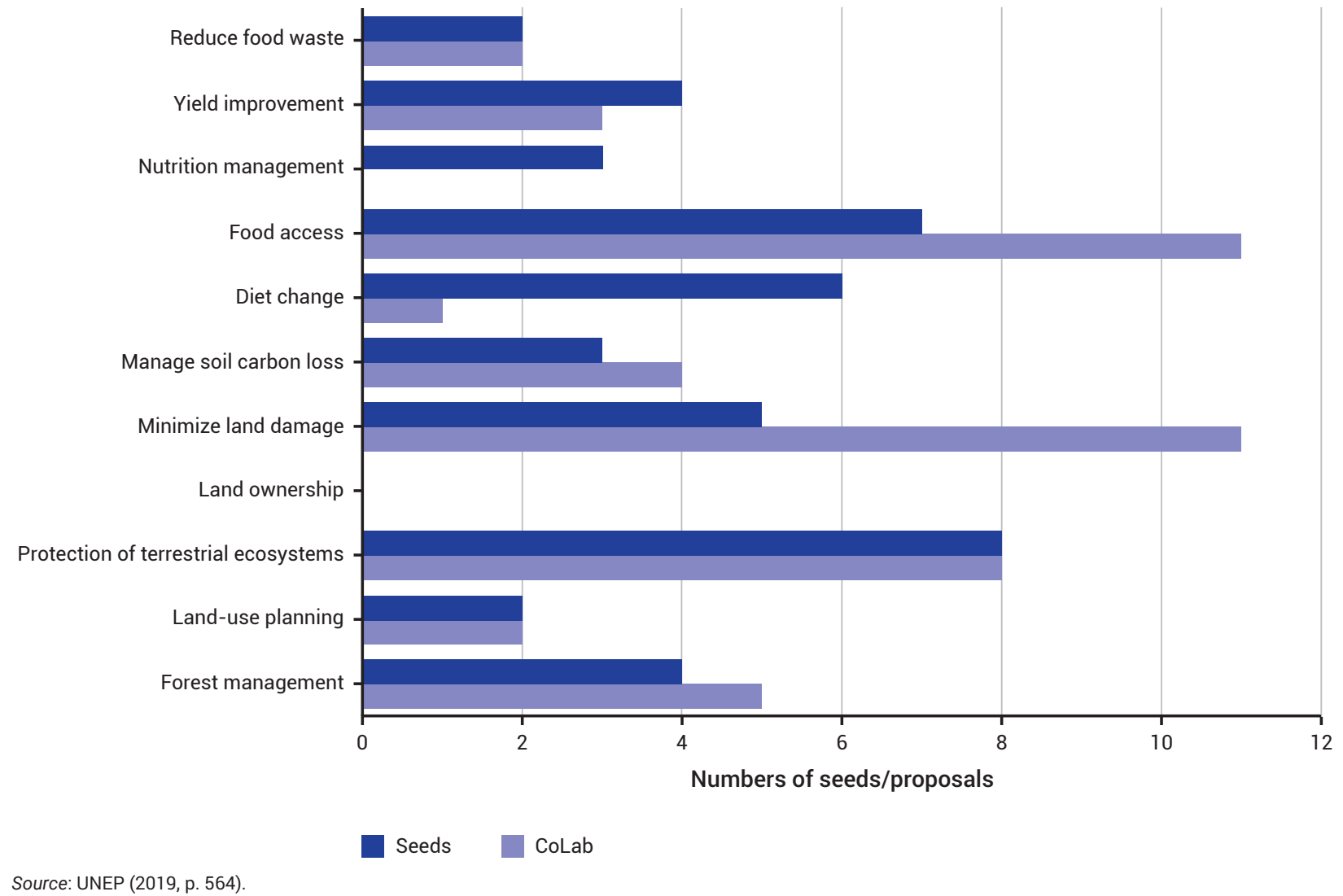


communities) were most represented. In the case of the Climate CoLab proposals, SDG 13 (climate action) was targeted by over 80 per cent of proposals, followed by SDG 3 (good health and well-being). $\{23.9 .2\}$

\section{Participatory approaches to identify and assess transformative solutions and envision pathways towards greater sustainability can provide decision makers with a useful landscape of initiatives and concrete synergistic solutions (established but incomplete). By engaging with stakeholders through global workshops and Climate CoLab, GEO-6 collected diverse solutions and visions that can complement (and potentially contribute to) quantitative information to be fed into integrated assessment models. For example, there was a strong emphasis on sustainable food systems as critical intervention points for moving towards a healthy planet and healthy people. $\{23.4\}$}

Many bottom-up visions for urban futures coalesce around building sustainable cities or communities. Urban areas are imagined in which buildings are fitted with solar panels and/or green roofs, built with sustainable materials, and use smart technologies to minimize energy use. Pathways to sustainable futures often included setting aside spaces and providing infrastructure to enable urban agriculture, the products of which could be used for food and sustainable consumer goods. One initiative focused specifically on an international cities platform allowing environmental data and actions to be aggregated internationally, and to be used by citizens to learn and to take part in sustainable community actions. $\{23.13\}$

Many solutions provide an opportunity for developing countries to leapfrog to more sustainable and equitable development trajectories. The use of information and communications technology (ICT) plays a major role in driving change in the bottom-up pathways towards sustainability: this is a result of a stronger focus on theories of change and on how change processes are facilitated. There are already many good examples of the way ICT is being leveraged for change in the global South. The roles of different societal actors and diverse knowledge systems are made explicit in bottom-up pathways. For example, in many proposals there is an important role for city-level government actors. The proposals also include a role for global networks of, for example, sustainable cities or energy cooperatives. Diverse higher-level enabling conditions such as international agreements, again tied to specific actors, are discussed as part of the bottom-up pathways and their seed initiatives. $\{23.13\}$

\subsection{Lessons learned}

Mainstreaming social and ecological dimensions into environmental and climate policies is critical for their success (well established). New policies should explicitly target women, indigenous peoples, family farmers, pastoralists and fishers, among other groups, so that they can have secure and equal access to land, resources, inputs, knowledge, financial services markets, and opportunities for adding value and nonfarm employment (established but incomplete). Closing the gender gap regarding access to and control over resources such as land and production inputs (and access to information and technology) would increase agricultural productivity and reduce poverty and hunger. $\{1.5 .1\}$

Policy design is at least as important as the choice of policy instruments for policy effectiveness (well established). Common elements of good policy design include: (i) establishing a long-term vision through inclusive, participatory design processes; (ii) establishing a baseline of environmental conditions, quantified science-based targets and milestones; (iii) effectively integrating environmental, social and economic concerns; (iv) conducting ex ante and ex post cost-benefit or cost-effectiveness analysis for optimal efficiency and effectiveness, and ensuring that social aspects are considered in sufficient detail; (v) building in monitoring regimes during implementation that support adaptive policies, ideally involving affected stakeholders; and (vi) conducting post-intervention evaluation of policy outcomes and impacts in order to close the loop for future policy design improvement. $\{11.2 .3\}$

Multilevel governance is a source of policy innovation (well established). MEAs support environmental policymaking at the national level to pursue related policies. Stakeholder participation in all phases of the policy cycle, from design to implementation to monitoring and evaluation, is crucial. At the subnational level communities, cities and the private sector are all establishing their own policy approaches, which is also supportive of advancing policies at other levels. $\{11.4\}$

\footnotetext{
An integrated approach is key for effective policies (well established). The integration of environmental concerns into various sectors at all levels (including agriculture, fisheries, tourism, forestry, industry, manufacturing and processing, energy and mining, transport, infrastructure and health) is key to effective protection of the environment. Social and economic
} 
aspects require careful consideration when environmental policy is being developed. Similarly, a gender-integrative approach could support more effective and transformative environmental policies and interventions. $\{11.3\}$

Successful models of environmental governance should be built upon well-designed policies and their implementation, compliance and enforcement. Such models should pay close attention to early signals from science and society and ensure adequate oversight capacity and investment in knowledge systems, such as data, indicators, assessments, policy evaluation and sharing platforms. Greater investment is needed in environmental and natural capital accounting systems to ensure that external costs are addressed and that processes are incorporated that will identify possible future risks, opportunities and conflicts. $\{18.3\}$

Greater application of the precautionary approach, in accordance with international agreements (where applicable), can reduce environmental and climate risk. (established but incomplete) Coalitions between government institutions, businesses and civil society to agree on pathways for tackling societal risks can achieve progress, even under conditions of great uncertainty. Multilevel coordination between local and national policy levels will be instrumental in accelerating the transition towards sustainable development models. $\{24.3 .4\}$

Environmental policies struggle with conceptual and empirical challenges, so that a good starting point for analysis is to determine what constitutes "good" policy design. Within the definition of good policy design, ecosystem properties and problems, and the performance of existing policies, practices and actors, should be considered as common elements. Analysts and policymakers need to better understand the temporal dynamics of policy change, how and why specific policies work (or do not work), and how policy choices interact in increasingly complex policy mixes. \{Chapter 11, ExecSum\}

Policy innovation can be regarded as a mix of invention (new or novel approaches), diffusion (transfer and adoption) and monitoring of effects (outcomes, impacts and possibly disruption). Good practice suggests that multiple innovative policies should be implemented as a form of quasiexperiment, with best practices emerging from the monitored effects. \{Chapter 11, ExecSum\}
Policy instruments working in silos are insufficient to stem environmental problems (well established). A key lesson learned is to carefully craft a mix of policies that are well aligned with an overall policy objective, followed by monitoring of the actual effects to determine best practice and the likely contributions of different policies. For example, climate change mitigation policy objectives need a comprehensive mix of carbon pricing, support for energy efficiency and renewable energy, phasing out of fossil fuel subsidies, innovation policies, prevention of the lock-in of certain technologies, and changes in consumer behaviour, among others. \{ Chapter 11, ExecSum\}

\section{Environmental objectives cannot be realized through environmental policies alone. They need to be incorporated in non-environmental policy sectors. Environmental ambitions often clash with other sectoral goals. Environmental policy integration should therefore be used to address conflicts between environmental and other policy objectives. A corollary to policy integration is policy coherence: the promotion of mutually reinforcing policy actions that create synergies towards achieving objectives in multiple sectors. \{ Chapter 11, ExecSum\}}

\section{Different investments are needed to improve} management capacity in different regions. For example, the GEO- 6 regional assessments identified improving air quality monitoring infrastructure as a priority for Africa and Latin America and improving the use of benefit-cost analyses of climate change and air pollution mitigation measures as a priority for Asia and the Pacific. \{Chapter 23, ExecSum\}

\section{Education for sustainable development is essential} to achieve the SDGs, promote a more sustainable society, and accommodate unavoidable environmental changes (well established). Significant progress has been made around the world in implementing education for sustainable development in all educational sectors. However, scaling it up is essential so that it can be included as a core element of education system structures globally. Policies that eliminate economic and gender barriers will improve access to education. Education for sustainable development can be scaled up through informal and non-formal education, including by the media. Community engagement and local (placebased) learning also have an important role to play. $\{4.2 .4\}$

Even achieving the SDGs and meeting other internationally agreed goals related to climate change, 
pollution control, clean-up and improved efficiency will not be sufficient (established but incomplete). Instead, transformative change, in the sense of reconfiguration of basic social and production systems and structures (including their institutional framework, social practices, cultural norms and values), is necessary. This requires a paradigm shift in thinking and approaches. Transformative change enables and combines visionary, strategic and integrated policymaking with the enabling of bottom-up social, technological and institutional innovation and the systematic use of experience drawn from such experimentation. $\{18.2\}$ 


\section{References}

Agrawal, A., Cashore, B., Hardin, R., Shepherd, G., Benson, C. and Miller, D. (2013). Economic contributions of forests. United Nations Forum on Forests Tenth Session. Istanbul, 8-19 April 2013. United Nations Forum on Forests http://www.un.org/esa/forests/pdf/session_documents/ unff10/EcoContrForests.pdf

Bourguignon, D. (2015). Safeguarding Biological Diversity - EU Policy and International Agreements. Brussels: European Union http://www.europarl.europa.eu/RegData/etudes/IDAN/2015/554175/ EPRS_IDA(2015)554175_EN.pdf

Buchner, B.K., Oliver, P., Wang, X., Carswell, C., Meattle, C. and Mazza, F. (2017). Global Landscape of Climate Finance 2017. Climate Policy Initiative. https://climatepolicyinitiative.org/wp-content/ uploads/2017/10/2017-Global-Landscape-of-Climate-Finance.pdf.

Ding, H., Veit, P.G., Blackman, A., Gray, E., Reytar, K., Altamirano, J.C. et al. (2016). Climate Benefits, Tenure Costs. The Economic Case for Securing Indigenous Land Rights in the Amazon. World Resources Institute. Washington, DC. http://wriorg.s3.amazonaws.com/s3fs-public/Climate_ Benefits_Tenure_Costs.pdf.

Food and Agriculture Organization of the United Nations (2005) Increasing the Contribution of SmallScale Fisheries to Poverty Alleviation and Food Security. FAO Technical Guidelines for Responsible Fisheries. Rome. http://www.fao.org/tempref/docrep/fao/008/a0237e/ a0237e00.pdf.

Food and Agriculture Organization of the United Nations (2015). Voluntary Guidelines for Securing Sustainable Small-Scale Fisheries in the Context of Food Security and Poverty Eradication. Rome. http://www.fao.org/policy-support/resources/resources-details/ en/c/418453/.

Food and Agriculture Organization of the United Nations (2016a). The State of World Fisheries and Aquaculture 2016: Contributing to Food Security and Nutrition for All. Rome. http://www.fao.org/3/ai5555e.pdf.

Food and Agriculture Organization of the United Nations (2016b). Technical and Socio-Economic Characteristics of Small-Scale Coasta Fishing Communities, and Opportunities for Poverty Alleviation and Empowerment. FAO Fisheries and Aquaculture. http://www.fao.org/3/ai5651e.pdf.

Food and Agriculture Organization of the United Nations (2018). The State of the World's Forest 2018: Forest Pathways to Sustainable Development. Rome. http://www.fao.org/3/ca0188en/ca0188en.pdf.

Garrett-Peltier, H. (2017). Green versus brown: Comparing the employment impacts of energy efficiency, renewable energy, and fossil fuels using an input-output model. Economic Modelling 61, 439-447. https://doi.org/10.1016/j.econmod.2016.11.012.

Intergovernmental Panel on Climate Change (2018). Global Warming of $1.5^{\circ} \mathrm{C}$ : An IPCC Special Report on the Impacts of Global Warming Of $1.5^{\circ} \mathrm{C}$ Above Pre-Industrial Levels and Related Global Greenhouse Gas Emission Pathways, in the Context of Strengthening the Global Response to the Threat of Climate Change, Sustainable Development, and Efforts to Eradicate Poverty. http://www.ipcc.ch/report/sr15/.

Intergovernmental Science-Policy Platform on Biodiversity and Ecosystem Services (2019). Summary for Policymakers of the Global Assessment Report on Biodiversity and Ecosystem Services of the Intergovernmental Science-Policy Platform on Biodiversity and Ecosystem Services. Bonn. https://ipbes.net/system/tdf/ipbes_7_10_ add.1_en_1.pdf?file=1\&type=node\&id=35329.

International Labour Organization (2016). Green Jobs: Progress Report 2014-2015. Geneva. https://www.ilo.org/wcmsp5/groups/public/--ed_emp/---emp_ent/documents/publication/wcms_502730.pdf International Labour Organization (2018). World Employment Social Outlook 2018: Greening with Jobs. Geneva. https://www.ilo.org/wesogreening/documents/WESO_Greening_EN_web2.pdf.

International Renewable Energy Agency (2017). Renewable Energy and Jobs: Annual Review 2017. Abu Dhabi. https://www.irena.org/-/media/ Files/IRENA/Agency/Publication/2017/May/IRENA_RE_Jobs_Annual_ Review_2017.pdf.

International Union for Conservation of Nature (2018). About: What is a protected area? https://www.iucn.org/theme/protected-areas/about Accessed 6 November 2018.

Organisation for Economic Co-operation and Development (2017) Healthy People, Healthy Planet: The Role of Health Systems in Promoting Healthier Lifestyles and a Greener Future. Paris. https://www.oecd.org/health/health-systems/Healthy-people-healthyplanet.pdf.

Ramsar Convention Secretariat (2018). Ramsar sites information service. https://rsis.ramsar.org/?pagetab=2 Accessed 15 October 2019

Renewable Energy Policy Network for the 21st Century (2018) Renewables 2018 Global Status Report. Paris. http://www.ren21.net/ gsr_2018_full_report_en

United Nations Environment Programme (2019a). Global Environment Outlook - GEO-6: Healthy Planet, Healthy People. Nairobi. https://wedocs.unep.org/bitstream/handle/20.500.11822/27539/ GEO6_2019.pdf?sequence=1\&isAllowed=y.

United Nations Environment Programme-World Conservation Monitoring Centre, International Union for Conservation of Nature and National Geographic Society (2018). Protected Planet Report 2018. Gland. https://livereport.protectedplanet.net/pdf/Protected_Planet_ Report_2018.pdf.

United States Department of Energy (2017). U.S. Energy and Employment Report January 2017. https://www.energy.gov/sites/prod/ files/2017/01/f34/2017\%20US\%20Energy\%20and\%20Jobs\%20Report_0. pdf.

Wei, M., Patadia, S. and Kammen, D.M. (2010). Putting renewables and energy efficiency to work: How many jobs can the clean energy industry generate in the US? Energy Policy 38(2), 919-931. https://doi. org/10.1016/j.enpol.2009.10.044.

World Bank (2017). World development indicators. http://datatopics. worldbank.org/world-development-indicators/ Accessed 24 September 2019 .

Yihdego, Y., Salem, H.S. and Pudza, M.Y. (2017). Renewable energy: Wind farm perspectives-the case of Africa. Journal of Sustainable Energy Engineering 5(4), 281-306. https://doi.org/10.7569/JSEE.2017.629521. 


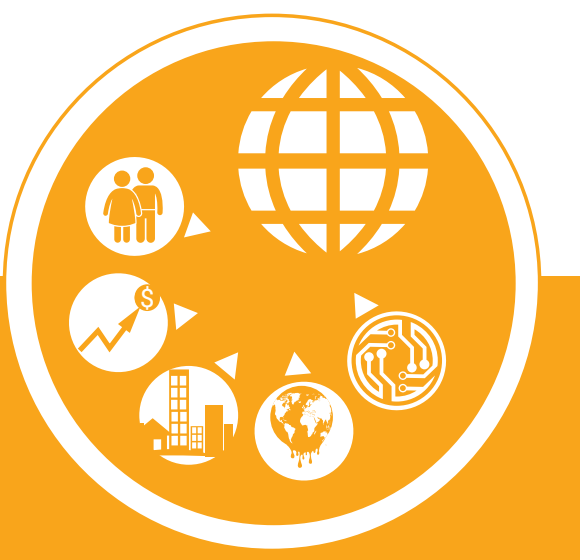

